\title{
Diets and living conditions of Asian boys in Coventry with and without signs of rickets
}

\author{
BY JANE O'HARA-MAY AND ELSIE M. WIDDOWSON \\ Department of Medicine, University of Cambridge, \\ Hills Road, Cambridge CB2 $2 Q Q$
}

(Received 20 August 1975 - Accepted 4 November 1975)

\begin{abstract}
I. The diets and living conditions of nine Asian boys with biochemical, and in most instances also radiological, signs of rickets were compared with those of nine other boys who appeared to be normal. The groups were matched according to age, religion, place of father's origin and boy's own place of birth.

2. There were no outstanding differences between the diets of the boys with, and of those without signs of rickets. All had adequate to high calcium intakes. Most of the boys had low intakes of vitamin D, and those with signs of rickets generally had lower intakes than the normal boys. The food tables used for making the calculations of vitamin $D$ intakes report the amount of the vitamin in the lipid fraction of milk. If it proves to be true that most of the vitamin D activity of milk is in the aqueous fraction, the boys would have been getting considerably more vitamin $\mathrm{D}$ than the results suggested, and their average intake may have been about $3.5 \mu \mathrm{g} / \mathrm{d}$.

3. It was not possible to make any quantitative measure of the exposure of the boys to sunlight. All Asian boys studied appeared to have their bodies more completely covered than British or West Indian boys.

4. The problem of why nine boys had signs of rickets and nine had none has not been solved. It is suggested that those with signs of rickets may have had higher requirements for vitamin $D$ than the others. When the intake of vitamin $D$ is low and exposure to sunlight is minimal, those with high requirements will be the ones to develop signs of rickets.
\end{abstract}

Rickets in infants and adolescents, and osteomalacia in pregnant women have been reported among Asian immigrants in several cities in Britain during the past 13 years (Dunnigan, Paton, Haase, McNicol, Gardner \& Smith, I962; Arneil \& Crosbie, 1963; Dunnigan \& Smith, I965; Felton \& Stone, I966; Swan \& Cooke, I97 I Clark, Simpson \& Young, 1972; Dawson \& Mondhe, 1972; Ford, Colhoun, McIntosh \& Dunnigan, I972a; Cooke, Swan, Asquith, Melikian \& McFeely, 1973). The diseases have been diagnosed clinically, radiologically and biochemically from the serum calcium concentrations and alkaline phosphatase $\left(E C_{3} \cdot\right.$ I $\cdot 3 \cdot$ I $)$ activities. Several suggestions have been put forward to explain the lack of vitamin $D$ and consequent appearance of the deficiency diseases in Asian immigrants. These include the fewer hours of sunshine in Britain compared with India and Pakistan, the failure to adapt to British dietary habits with their supposed higher inclusion of foods containing vitamin $D$, and a large consumption of chupatties containing much phytate which interferes with the absorption of $\mathrm{Ca}$. Studies over a period of time, however, have produced various relevant facts, one of which is that rickets and osteomalacia are still common in cities in Northern India (Vaishnava \& Rizvi, 1967, 1971, 1973). Also, Holmes, Enoch, Taylor \& Jones (I973) have suggested that the change in residence from India to Britain is quite irrelevant in the incidence of the disease, except that the smaller amount of sunshine in Britain is likely to aggravate the situation. 
It is undoubtedly true that many Indians and Pakistanis retain their accustomed foods, and among these an important item is chupatties. Ford, Colhoun, McIntosh \& Dunningan ( $1972 b$ ) gave bread instead of chupatties for 7 weeks to eight Pakistani children and two women with osteomalacia, and found that their serum $\mathrm{Ca}$ and phosphorus concentrations, and alkaline phosphatase activities increased, which the authors interpreted as indicating healing bone disease. They thought that the high phytate content of the chupatties prevented the absorption of $\mathrm{Ca}$, and suggested that the simplest prophylactic measure would be to fortify the high-extraction flour used for making chupatties with additional Ca. Dent, Round, Rowe \& Stamp (I973), on the other hand, concluded that the importance of chupatties and phytate was negligible, and emphasized that the fundamental problem must be the lack of sunlight and vitamin $\mathrm{D}$.

As part of a general survey of rickets among Asian immigrants the sera of 353 European (mainly British), West Indian and Asian schoolboys living in Coventry in r 973-4 were analysed for Ca concentration and alkalire phosphatase activity. Of these boys, nine Asians had high activities of alkaline phosphatase and low concentrations of $\mathrm{Ca}$ in the serum (T. B. Whitehead $\&$ L. S. Culank, personal communication). The present study was made to try to determine why these particular boys had biochemical signs of rickets, while others did not. It was agreed that these nine boys should be studied in more detail, together with nine other boys whose serum Ca concentrations and alkaline phosphatase activities, determined at the same time as the others, were within normal limits. All eighteen boys were examined clinically and radiologically, and a further sample of blood was taken for analysis. The boys took part in a dietary and environmental study, which is reported in the present paper.

\section{EXPERIMENTAL}

\section{Subjects}

Of the nine boys who had had biochemical signs of rickets in winter and early spring, three were Hindus, three Sikhs and three Moslems. The choice of subjects on physical grounds alone resulted in the inclusion of some boys whose ability to understand and write English was limited. One boy completed his dietary record in Punjabi.

Nine 'controls' with normal blood chemistry had to be chosen from sixteen Hindus, twenty-three Sikhs and six Moslems attending the same schools. The selection of the controls was based primarily on age and religion, but parents' place of origin and the boy's period of residence in the UK were also considered. The choice was further restricted to boys who were willing and able to participate, and who had no history of metabolic disturbance or prolonged drug treatment.

Of the sixteen Hindu boys who might have been available only two corresponded in age with the subjects; the others were all younger. It was decided, after discussion with the families about their dietary habits, to match the third Hindu subject with a Sikh boy of similar age from the same geographical area. In the instance of the Sikhs, age and parents' place of origin could be matched satisfactorily, but not the birthplace of the boy himself. 
Vol. $3^{6}$
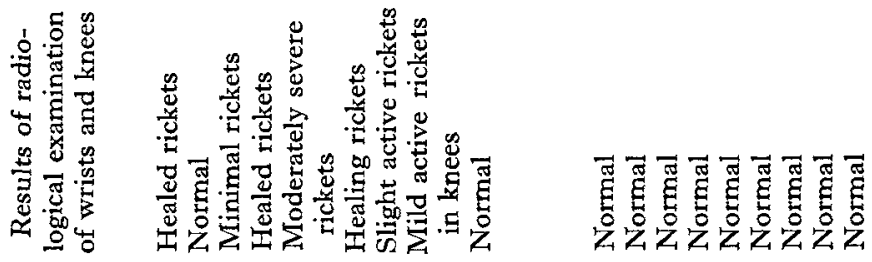

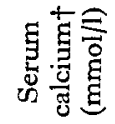

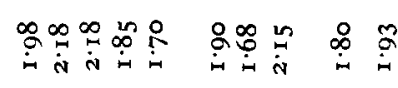

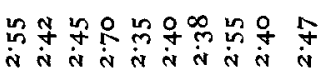

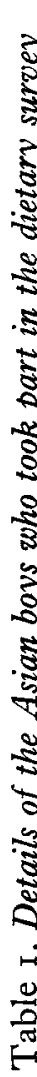

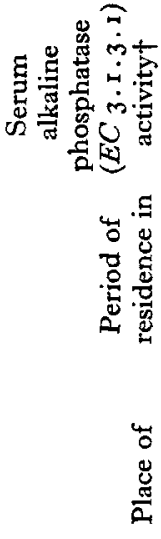

岁.

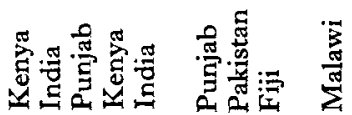

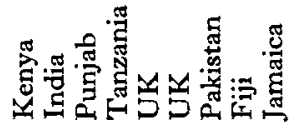

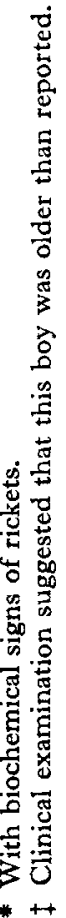

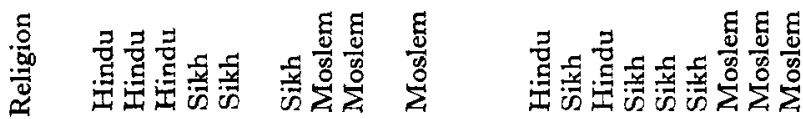

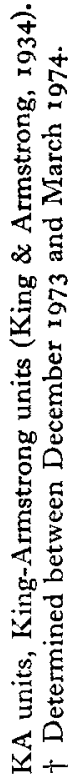

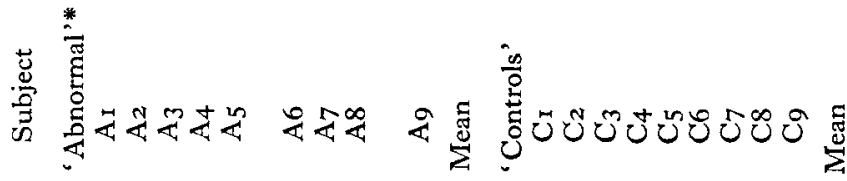


The boys who had had biochemical signs of rickets earlier in the year were studied during June and July 1974 before the school term ended, and four of them had school dinners on one or more occasions. The normal control subjects were studied during August 1974, after the term had ended. Two of them were by then in full-time employment and two had holiday jobs. School dinners, of course, were not available, although six of the boys said they had taken school dinners during the previous term. Thus, the timing of the dietary and environmental study was not ideal, but it was dictated by circumstances outside our control.

All the boys attended the Warwick and Coventry Hospital for clinical, radiological and biochemical investigation just before the dietary study on the group began, and they were all weighed and measured. This gave the opportunity to meet the boys and arrange the first visit to their homes. The results of these clinical, radiological and biochemical investigations were not available until after the dietary survey had been completed. When a diagnosis of active rickets had been made, the parents and doctors of the boys concerned were informed and treatment with vitamin $D$ was started immediately. The boys had been weighed and measured when they first entered school after arriving in UK, but thereafter records of heights and weights were not maintained sufficiently to enable any conclusions to be made about rate of growth at any particular time.

Some details about the individual boys taking part in the study are given in Table $\mathbf{I}$. All the 'abnormal' boys, i.e. those with biochemical signs of rickets, were below the 5 oth centile line for weight (Tanner, Whitehouse \& Takaishi, I966), but only five of the 'controls' were below this line. Four 'abnormal' boys and one 'control' were below the roth centile. Seven of the nine boys with biochemical indications of rickets also showed radiological signs of active or healed rickets in their wrists and knees. All the boys acting as 'controls' had normal bones.

\section{Methods}

One of us (J. O'H.-M.) lived in Coventry for the 2 months of the survey and was responsible for collecting all the information. A doctor attached to the Coventry Area Health Authority, Dr S. Verma, who had good knowledge of Asian languages and background, and a respected status among the Asian community, helped us to start the survey on a firm foundation of co-operation, gave an entry into the families involved, and avoided possible friction which might have resulted with an inquiry of this type. Dr Verma accompanied the investigator on at least one visit to every family. All the boys taking part spoke and understood English, though some with difficulty; few of their mothers knew more than the occasional word.

Dietary survey. The method was that used by Widdowson (1947), i.e. a $7 \mathrm{~d}$ individual weighed-food intake. The boys were each supplied with scales (accurate to the nearest $0.25 \mathrm{oz}(7 \mathrm{~g})$ ), a plate, a notebook for items eaten away from home, and a 'log-book' for each day's weighed intake. Those taking school meals met the investigator at the school lunch servery and weighed their food with her. Otherwise, each boy was responsible for completing his own records. Where there was a schoolgirl sister she helped her brother with the recording. The minimum number of visits 
made by the investigator was four. These always included one on a preliminary day for instruction, one on the second day to deal with any difficulties, and the other two on the sixth and eighth days for collection of the records. In difficult situations as many as eight visits were made. The instructions and collection followed the same pattern for those subjects with, and those without biochemical signs of rickets. The instruction took place either at lunch-time or after school or work, in the presence of the mother (or, in her absence, an adult sister). Brothers, sisters and, in most instances, an adult male member of the family were also present. In families where the Asian custom of taking small helpings of food several times during a meal was followed, it was arranged that the subject should be given his own bowls of weighed food from which he helped himself, and any uneaten food was weighed at the end of the meal. However, many of the families had adopted a European style of eating, so this was not necessary.

The scales to be used were demonstrated and their use practised both with individual items and by the gradual addition of items. The method of using the 'log-book' was described, special emphasis being placed on the fact that meals and dishes are made up of individual foods. A sample 'log-book' was studied and a spare sheet used to practise recording that day. The survey started on the next day.

In addition to the weights of food eaten each day, all 'log-books' recorded the type of chupatty flour, butter or margarine, fat or oil, bread and milk used in the home. Any foods that the subject could not take, and any particular likes and dislikes were noted.

Because of unusual spelling and the boys' difficulty with English food names most ' log-books' required some 'interpretation' by the investigator. If Indian names only had been used translations were made by Dr Verma. Foods were sometimes identified by the use of a 'sample card' made up of various pulses, or by reference to a standard English-language Indian cookery book.

The notebooks recording foods eaten away from home, e.g. 'fish and chips', gave information about the place of purchase and cost. The investigator subsequently visited the shop or café, bought a similar portion of food and weighed it.

The Asian families drank very sweet tea, and milk and sugar were boiled with the tea in quantities sufficient for the whole family. Some of the boys were able to make their tea separately, and for others the proportions of milk and sugar used in making the family tea were taken as representative, and the amounts in one cup of tea calculated.

The records collected on the sixth day were studied in detail (even if they had been studied on previous visits) and then clarified on the eighth day when the remaining records for days 6 and 7 and the scales were collected.

The usual period for instruction was about $\mathrm{I} h$ (maximum $90 \mathrm{~min}$, minimum $40 \mathrm{~min}$ ). The timing of this and subsequent visits depended on the subject's activities. The shortest duration of a subsequent visit was $15 \mathrm{~min}$, but the investigator might stay talking to the boy or his brother and sisters for $30-60 \mathrm{~min}$. The final visit usually took about 30-45 min.

Circumstances demanded that the survey should be completed in the shortest 
possible time. The first ten boys (all those with biochemical signs of rickets and one 'control') were studied between 30 June and i9 July i 974 . The dietary survey on the remaining eight 'normal control' boys was made between 3 I July and 22 August I974. The maximum number of dietary surveys made concurrently was four. One boy (subject A9) failed to complete his dietary record and he has not been included in the results of the dietary survey.

The chemical composition of the diets was calculated using the tables of Platt (1962), Watt \& Merrill (1963), Mann \& Crowdy (1966), Fox (1966), McCance \& Widdowson (1967), Ministry of Agriculture, Fisheries and Food (1970) and Gopalan, Rama Sastri \& Balasubramanian (I97I). The values from these tables were supplemented by some new analyses of British and Asian foods (D. A. T. Southgate \& A. Paul, personal communication). For vitamin $\mathrm{D}$, as well as other nutrients, values for cooked foods were used where appropriate, both for meals eaten at home and at school. The school lunch, however, often consisted of a salad with eggs, cheese, sausage rolls or luncheon meat.

Since chupatties formed an important part of the diet, particular attention was paid to the flour used for making them. None of the flour supplied to Asian immigrants in the UK and designated 'chupatty flour' is wholemeal in the true sense of the term: it is white flour which has had variable amounts of bran and offals added, and been ground to various extents of fineness according to the requirements of the population in the area where it is to be sold. Chupatty flour made from a base of white flour contains the calcium carbonate added by law to all white flour sold in the UK, and this increases the $\mathrm{Ca}$ content to approximately $\mathrm{I} \cdot 45 \mathrm{~g} \mathrm{Ca} / \mathrm{kg}$. The phytate content depends on the amount of milled bran included in the flour and, according to the values of A. N. Hartley (personal communication), varies from 0.5 to $\mathrm{I} \cdot 4 \mathrm{~g}$ phytate-P $/ \mathrm{kg}$ flour.

In the Coventry area the flour comes from six main mills, and each mill makes several kinds of chupatty flour. One, for example, produces Superfine, Champion No. $\mathrm{I}$ and Champion No. 2, corresponding approximately to 75,80 and $85 \%$ extraction flour respectively. Another makes two flours of the same composition but of different extents of fineness.

Plain chupatties are made from a dough of flour and water, which is cooked on a griddle. Sometimes a little ghee (clarified butterfat from which water has been evaporated) is added to the dough during mixing. The chupatties may be eaten with or without a little butter spread on them. Alternatively, plain chupatties, after they have been cooked, may be fried in ghee. Parauthas are another variety of chupatty. The dough of flour and water is rolled out, ghee or butter folded in, and the dough rolled out again and cooked on the griddle.

Seven samples of newly-made chupatties and four samples of parauthas were obtained from Hindu, Sikh and Muslim families, and the moisture and fat content determined. The plain chupatties contained an average of $260 \mathrm{~g}$ water and $\mathrm{r} 3 \circ \mathrm{g}$ fat $/ \mathrm{kg}$.

Environmental study. This was a qualitative assessment of each boy's environment, limited in scope because of the short period available for the whole survey. The objectives were to obtain an estimate of each boy's exposure to sunlight, to look for 
signs in the home of dietary restriction caused by lack of money, and to consider whether any obvious stresses in the family would be likely to affect the boy's eating habits. The weather on each day of the study period was noted, but it soon became obvious that the number of $h$ of sunshine recorded by the Meteorological Office gave no indication of clothes likely to be worn, as the sunshine was frequently accompanied by a cold wind. The clothes actually worn by subjects and by other Asian schoolchildren were noted, and during the meeting at the clinic, boys were questioned about the clothes they wore in summer and winter, with particular reference to long- and short-sleeved clothing and trousers. Each boy was asked about his activities indoors and outdoors, and the time he spent in the open-air. This was checked by observation whenever possible. There was no obvious source of air pollution near any of the homes. The style of houses, furnishings and number of 'durable luxuries', e.g. television, refrigerator, tape recorder, wall-to-wall carpeting, new furniture, central heating, car and telephone, were used to make a rough code of 'affluence'. The father's work in Coventry (or elsewhere) was recorded, also the number of persons living in the home and their age and sex. Family relationships were observed where possible, and difficulties such as family illnesses, absence of father or mother, or a very dominant parent were noted. Much of the information came from Dr Verma's conversations with the family, and also from the schoolteacher's knowledge of the boy and his background. The boy's health and educational records were also available for inspection.

RESULTS

\section{Dietary survey}

The diets in terms of foods. Table 2 gives the mean amounts ( $\mathrm{g} /$ boy per $\mathrm{d}$ ) of the most common foods eaten. Some of the boys did not eat every food during the week, and the number of boys taking each food is given in parentheses. The mean values were calculated as: total amount eaten by the group $\div$ total number of boys in the group.

Every boy ate chupatties and the mean daily consumption was about $230 \mathrm{~g}$ for the two groups. This is more than other workers have reported for Pakistani women and children (Ford $e t a l$. $1972 b$ ). The mean daily consumption of chupatties (g) by the boys were: Hindus 160, Sikhs 260, Moslems 250. Two boys with signs of rickets ate no bread, while four 'control' boys ate more bread than any of the other subjects; they had bread at two meals/d or took a 'sandwich' lunch to work. This explains the higher mean bread intake by the 'control' boys.

All the boys drank milk, and the mean consumption was about 0.8 pints $(454 \mathrm{ml}) / \mathrm{d}$. Hindus, Sikhs and Moslems drank about the same quantity. Eleven of the seventeen boys ate yoghurt, and the consumption in both groups averaged about $35 \mathrm{~g} / \mathrm{d}$.

More of the control boys ate eggs; they ate an average of between four and five eggs/week as compared with an average of a little more than one egg/week for those with signs of rickets. Of those who recorded eating cheese the two 'abnormal' boys had it in school meals, and the 'controls' ate cheese rolls outside the home.

Most of the spreading fat was butter or ghee; the ghee was always prepared from 


\section{Table 2. Mean intakes of foods by Asian boys who took part in the dietary survey}

(Mean values for the most common foods eaten ( $g /$ boy per $\mathrm{d}$ ), calculated as: total amount eaten by the group $\div$ total no. of boys in the group; no. of boys eating each food is given in parentheses)

Chupatties
Bread
Biscuits
Cakes and pastry
Milk
Yoghurt
Eggs
Cheese
Butter, ghee*
Margarine
Meat, chicken and fish
Fruit
Pulses (cooked weight)
Baked beans (tinned)
Potatoes
Green vegetables
Other vegetables
Cane sugar
Sweets and chocolate
Soft drinks

$\begin{array}{cc}\text { Boys with bio- } & \\ \text { chemical signs of } & \text { Normal controls } \\ \text { rickets }(n 8) & (n 9)\end{array}$

* Clarified butterfat from which water has been evaporated.

butter. Two 'abnormal' boys and one 'control' subject recorded eating margarine, but both took butter or ghee as well.

Two Hindu boys with signs of rickets, and one 'control' subject had no meat, chicken or fish during the week. All the others ate some meat or chicken or both. Three boys ate fish: one in each group, both born in Fiji, ate tinned fatty fish; the third, in the 'control' group, who came from Jamaica, ate stockfish (dried salt cod).

All boys except one ate some fruit (including tomatoes). The main vegetables eaten were pulses and potatoes, but the list included carrots (Daucus carota), cauliflower (Brassica oleracea botrytis), aubergine (Solanum melongena), marrow (Cucurbita pepo) and okra (Hibiscus esculentus). Most of the pulses were Indian dhals, but peas were also eaten by most of the boys. Baked beans are the only form of tinned British foodstuff popular among the Asian community in Coventry, and appeared in the diets of four of the 'abnormal' boys and in five of the 'controls'. The potatoes were eaten in various forms, boiled, mashed, roast, chipped, and mixed with dhals and other vegetables.

Soft drinks were popular; most boys had them, and the average consumption was about $\mathrm{I} \cdot 5$ pints $(825 \mathrm{ml}) / \mathrm{d}$.

The diets in terms of nutrients. Table 3 gives the amounts of energy, protein, fat, $\mathrm{Ca}$, total and phytate-P, vitamin $\mathrm{D}$, ascorbic acid and iron provided by the mean amount of food eaten daily for each of the seventeen boys taking part in the dietary survey. 


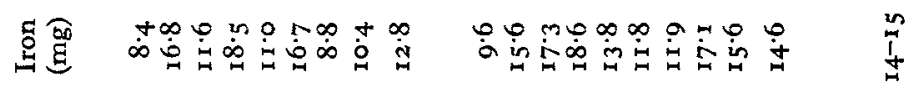

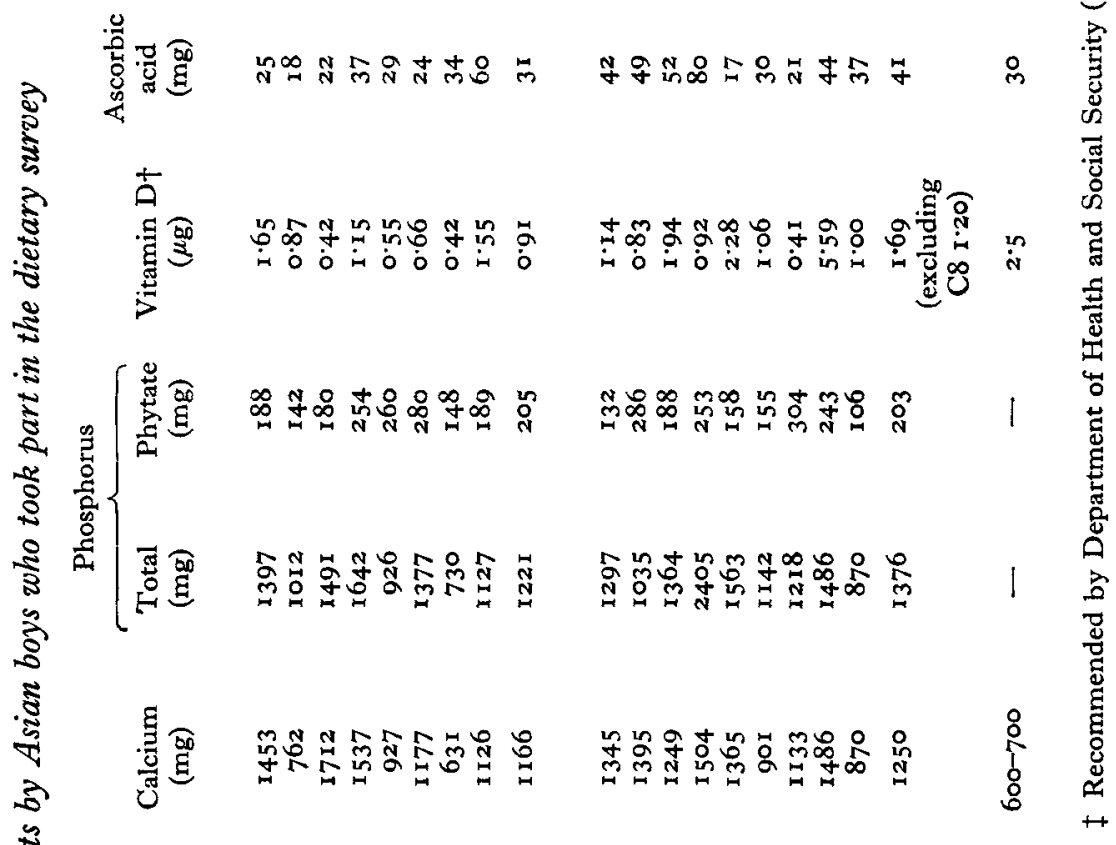

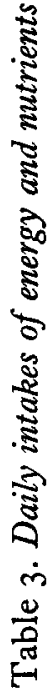

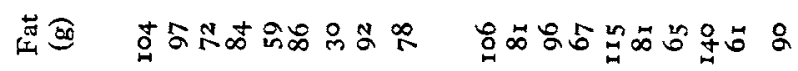

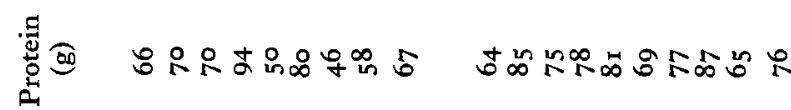

in

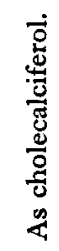

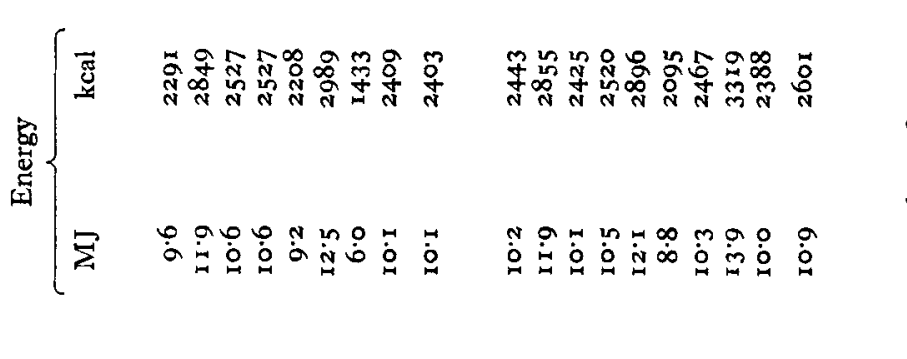

若

苞

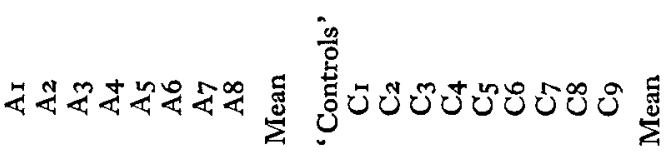

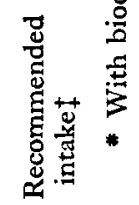


Recommended intakes for the UK (Department of Health and Social Security, I969) are given for comparison.

The energy intakes were generally lower than those recommended for boys of the same ages in the UK, but the Asian boys were smaller than British boys of the same age, and their mean energy intakes expressed on a 'per kg body-weight' basis (boys with signs of rickets $2 \mathrm{I} 3 \mathrm{~kJ}\left(5^{\mathrm{I}} \cdot \mathrm{O} \mathrm{kcal}\right) / \mathrm{kg}$ body-weight, 'controls' $202 \mathrm{~kJ}(48 \cdot 2 \mathrm{kcal}) / \mathrm{kg}$ body-weight) were slightly higher than the recommended values (199 kJ ( $47.5 \mathrm{kcal}) /$ $\mathrm{kg}$ body-weight).

One of the chief sources of energy was chupatties; these provided four boys with more than $30 \%$ of their energy, and the mean values were 23 and $21 \%$ for 'abnormal' and 'control' boys respectively. Milk provided 18 and $15 \%$ for the two groups, and cane sugar about $7 \%$ for both groups.

Protein intakes were adequate in most instances. Two boys with signs of rickets had less than the recommended intake of $58 \mathrm{~g} / \mathrm{d}$. One of these (subject $\mathrm{A}_{5}$ ) ate no meat, chicken, fish, eggs or cheese. The other boy (subject $\mathrm{A}_{7}$ ) ate considerably less food than any of the others. In both groups $46 \%$ of the protein came from animal sources, of which milk was the most important (28 and $22 \%$ for 'abnormal' and 'control' boys respectively). Chupatties provided about $20 \%$ of the protein in both groups.

Intakes of fat by both groups were very variable, from 30 to $104 \mathrm{~g} / \mathrm{d}$ for the 'abnormal' boys and from 6I to $140 \mathrm{~g} / \mathrm{d}$ for the 'controls'. Subject C8, who had the highest intake of fat, ate large quantities of fried chupatties and his butter intake was also high. Channel Island milk also provided some of the boys with a considerable amount of fat.

Perhaps the most surprising finding in this part of the study was the large amounts of $\mathrm{Ca}$ these boys were taking in their diets. No boy had an intake of less than $600 \mathrm{mg} / \mathrm{d}$, and the mean value for both groups was greater than rooo $\mathrm{mg}$. The main source of $\mathrm{Ca}$ was milk, which provided about $50 \%$ of the intake in both groups. Chupatties contributed $19 \%$ of the $\mathrm{Ca}$ in the diets of the 'abnormal' boys and $16 \%$ in those of the 'controls'. If the flour from which they were made had not been fortified with $\mathrm{Ca}$ the total $\mathrm{Ca}$ intake would have been reduced by approximately $170 \mathrm{mg} / \mathrm{d}$ for the boys in both groups, and the mean $\mathrm{Ca}$ intake would have been approximately $1000 \mathrm{mg} / \mathrm{d}$. The intakes of $\mathrm{Ca}$ were much higher than the amounts that would have been precipitated and made unavailable by the phytic acid (McCance \& Widdowson, 1942), and the boys should have had enough available $\mathrm{Ca}$ for absorption.

The intakes of vitamin $\mathrm{D}$ were low, and generally the boys with signs of rickets had less than the normal 'controls'. Only one boy had more than the recommended intake of $2.5 \mu \mathrm{g} / \mathrm{d}$, and eight had an intake of less than I $\mu \mathrm{g} / \mathrm{d}$. Margarine, which is fortified with vitamin $\mathrm{D}$, only appeared in three of the diets, and the boys who ate it, subjects $\mathrm{A}_{1}, \mathrm{~A}_{2}$ and $\mathrm{C}_{5}$, obtained $40-55 \%$ of their vitamin $\mathrm{D}$ from margarine. Eggs were an important source of vitamin $\mathrm{D}$ to the boys who ate enough of them, but only one boy (subject $\mathrm{C}_{3}$ ), who ate $673 \mathrm{~g}$ fried eggs during the week, obtained > I $\mu \mathrm{g}$ vitamin $\mathrm{D} / \mathrm{d}$ from them. The boy who ate tinned fatty fish more than once during the week (subject $\mathrm{C} 8$ ) obtained an average of $4 \cdot 3 \mu \mathrm{g}$ vitamin $\mathrm{D} / \mathrm{d}$ from his pilchards and sardines. 
If his intake was included, the mean vitamin $D$ intake for the 'control' group was $\mathrm{I} \cdot 7 \mu \mathrm{g}$ vitamin $\mathrm{D} / \mathrm{d}$; if subject $\mathrm{C} 8$ was excluded the mean value was $\mathrm{r} \cdot 2 \mu \mathrm{g} / \mathrm{d}$. The mean intake for the boys with biochemical signs of rickets was $0.9 \mathrm{I} \mu \mathrm{g} / \mathrm{d}$.

Three 'abnormal' boys and seven 'controls' had an ascorbic acid intake of more than $30 \mathrm{mg} / \mathrm{d}$. Subject A7 obtained most of his ascorbic acid from oranges, subject A8 from Ribena (Beecham Foods, Brentford, Middx.), and subject $\mathrm{A}_{4}$ from vegetables. Subject C8 ate guavas (Psidium guajava), but the other 'controls' got their ascorbic acid from a variety of vegetables, including red peppers (Capsicum spp.) and tomatoes.

The Fe intakes of most of the boys were similar to the recommended intake of I4-I $5 \mathrm{mg} / \mathrm{d}$. Two boys had considerably lower intakes; however, their haemoglobin concentrations determined earlier in the year, $164 \mathrm{~g} / 1$ for subject $A_{\mathrm{r}}$ and ${ }_{13} 6 \mathrm{~g} / \mathrm{l}$ for subject $\mathrm{A}_{7}$, did not suggest that they were Fe-deficient.

\section{Environmental study}

Exposure to sunlight. The method of questioning and intermittent observation used in this survey was inadequate to obtain a quantitative assessment of the boys' exposure to sunlight. All boys customarily wore garments with long sleeves, and long trousers during the period of the survey, even those who had indicated that they wore short sleeves in the summer. One boy (subject $\mathrm{C}_{9}$ ), however, wore his sleeves rolled up. From general observation at the two schools and in the streets near the subjects' homes, it appeared that Asian boys started to wear long trousers when they were younger than British or West Indian boys. Asian girls observed at the schools frequently wore long socks (to below the knee) and mini-skirts; thus they may have had more benefit from the sunlight than the boys. A period of observation at a council housing estate with mixed racial groups showed that on the one really hot day, though many British and West Indian children wore only a pair of shorts, no Asian children were dressed in as little as this.

Questionnaires about outdoor activity can be misleading. Sometimes the boys did not seem to realize what was meant by time spent out-of-doors. One did not mention, for example, but was observed, doing week-end work in the forecourt of a garage cleaning cars and serving petrol, and another did a regular paper-round twice/d, of duration approximately $30-45 \mathrm{~min}$.

Many of the activities referred to by the boys took place indoors at the community facilities provided by the school. Even football played outdoors did not give the exposure to sunlight one might have expected, for Asian boys often played in their own jeans and shirts and not in football clothes. Indeed, the boys did not appear to have much exposure to sunlight, but no differences could be detected between the groups.

Most of the gardens were small, but three of the families were found sitting in them when visits were paid to the homes.

Financial position. No family appeared to suffer from serious poverty. All the boys except one lived in terrace-houses of various ages but similar size. Most families obviously took pride in the cleanliness, appearance and comfort of their homes. Using 
an arbitrary scale of I (well-furnished and comfortable) to 3 (best efforts with restricted money) and 4 (disorganized), the homes were assessed as follows:

$\begin{array}{ccc}\text { Scale } & \text { No. in 'abnormal' } & \text { No. in 'control' } \\ \text { group } & \text { group } \\ \text { r } & 1 & 2 \\ 2 & 4 & 5 \\ 3 & 2 & 2 \\ 4 & 2 & 0\end{array}$

The home surroundings were therefore generally better for the 'control' boys than for those with signs of rickets. Because there is usually considerable movement between the homes within an Asian extended family, no precise indication of occupants: rooms can be given.

The occupations of the fathers were similar in the two groups, and included carpenter, baker, crane-driver, machine-operator and car worker. The father of one 'abnormal boy' was not in England, and that of another boy lived separately from the mother.

Stresses within the family. Most of the eighteen families appeared to be close-knit, but the pressures on intelligent boys to succeed in their school studies was obvious. Seven boys in each group were assessed by their teachers as average or above-average in intelligence. The need for hard work was taken seriously by the boys themselves.

Reported or observed difficulties within the families suggested that the problems were marginally greater for the 'abnormal' boys than for the 'controls'. Four boys with signs of rickets had one or both parents absent (or dead) and one of the parents of two others had been or was ill. Among the 'controls' the corresponding numbers were two and one.

\section{DISCUSSION}

There were no outstanding differences between the diets of the boys with and without signs of rickets, and the results as a whole are similar to those of Ruck (1974) for Asian schoolchildren in Birmingham.

All the boys had adequate to high $\mathrm{Ca}$ intakes. The $\mathrm{Ca}$ was derived mainly from milk (about $50 \%$ ) and chupatties (16-19\%), which were made from enriched white flour with added bran. The high intake of $\mathrm{Ca}$ relative to phytate-P suggested that it was very unlikely that the phytate in the diet was involved in the appearance of rickets among this particular group of immigrant Asian boys.

Most of the boys had low intakes of vitamin $\mathrm{D}$, and those with abnormal serum Ca concentrations and alkaline phosphatase activities tended to have lower intakes than the normal 'control' boys. It is possible that the actual intakes were higher than the calculated intakes, as it has been suggested that most of the vitamin D activity of cow's milk is present in the aqueous fraction as vitamin D sulphate (Sahashi, Suzuki, Higaki \& Asano, 1967; Le Boulch, Gulat-Marnay \& Raoul, 1974). This was not included in the values for vitamin $\mathrm{D}$ given in food tables, where the activity in the lipid fraction only was considered. If the milk (and yoghurt) these boys consumed contained $5 \mu \mathrm{g}$ vitamin $\mathrm{D} / \mathrm{l}$ in the aqueous fraction, approximately $2.5 \mu \mathrm{g}$ vitamin $\mathrm{D}$ should be added 
to the calculated mean daily intake in both groups, to give a total vitamin D intake of approximately $3.5 \mu \mathrm{g} / \mathrm{d}$. Only four boys, three with signs of rickets and one without, would have had less than the recommended intake of $2 \cdot 5 \mu \mathrm{g} / \mathrm{d}$.

It was not possible to make any quantitative measurement of exposure of the boys to sunlight. All the boys wore long trousers and long-sleeved pullovers or jackets, and appeared to have their bodies more completely covered than British or West Indian boys. No differences were detected between the clothing or out-of-door activities of the boys with and without signs of rickets.

The problem of why nine Asian boys had biochemical signs of rickets and nine had none has not been solved by this survey. Requirements for vitamin $D$, as for other nutrients, undoubtedly vary from one individual to another, and when the dietary intakes of most individuals are very low, and all individuals have low exposure to sunshine, those with high requirements will be the ones who develop signs of rickets.

The authors thank the following people for their help during this study: Dr G. T. Pollock, Area Medical Officer, and Dr M. M. R. Gaffney and her staff of the Coventry Area Health Authority, and Dr S. Verma, Dr A. C. Kendall and Miss P. Whitehall; Professor 'T. P. Whitehead and Dr L. S. Culank, East Birmingham Hospital, Birmingham; Dr D. Fernando, London School of Hygiene and Tropical Medicine, London; the Director of Education in Coventry, and the Headmasters and staff of Foxford and Sidney Stringer Schools, Coventry, and also the schools' meals supervisor and staff at these schools; all eighteen boys and their families.

They thank also the Department of Health and Social Security and the Medical Research Council for their support.

\section{REFERENCES}

Arneil, G. C. \& Crosbie, J. C. (1963). Lancet ii, 423.

Clark, F., Simpson, W. \& Young, J. R. (1972). Proc. R. Soc. Med, 65, 478.

Cooke, W. T., Swan, C. H. J., Asquith, P., Melikian, V. \& McFeely, W. E. (1973). Br. med. Y. i, 324.

Dawson, K. P. \& Mondhe, M. S. (1972). Practitioner 208, 789.

Dent, C. E., Round, J. M., Rowe, D. J. F. \& Stamp, T. C. B. (1973). Lancet i, 1282.

Department of Health and Social Security (1969). Rep. Publ. Hlth med. Subj., Lond. no. I 20.

Dunnigan, M. G., Paton, J. P. J., Haase, S., McNicol, G. W., Gardner, M. D. \& Smith, C. M. (I g62). Scott. med. Y. 7, I59.

Dunnigan, M. G. \& Smith, C. M. (1965). Scott. med. F. ro, r.

Felton, D. J. C. \& Stone, W. D. (I966). Br. med. F. ii, r521.

Ford, J. A., Colhoun, E. M., McIntosh, W. B. \& Dunnigan, M. G. (1972a). Br. med. F. ii, 677.

Ford, J. A., Colhoun, E. M., McIntosh, W. B. \& Dunnigan, M. G. (1972 b). Br. med. 7. iii, 446.

Fox, F. W. (1966). Studies in the Chemical Composition of Foods Commonly Used in South Africa. Johannesburg: South African Institute for Medical Research.

Gopalan, C., Rama Sastri, B. \& Balasubramanian, S. C. (1971). Nutritive Value of Indian Foods. Hyderabad: Indian Council of Medical Research.

Holmes, A. M., Enoch, B. A., Taylor, J. L. \& Jones, M. E. (1973). Q. Fl Med. 42, 125.

King, E. J. \& Armstrong, A. R. (1934). Can. med. Ass. 7. 31, 376.

Le Boulch, B., Gulat-Marnay, C. \& Raoul, Y. (1974). Int. Z. VitamForsch. 44, 167.

McCance, R. A. \& Widdowson, E. M. (1942). Y. Physiol., Lond. ror, 44.

McCance, R. A. \& Widdowson, E. M. (1967). Spec. Rep. Ser, med. Res. Coun. no. 297.

Mann, G. M. \& Crowdy, J. P. (1966). Ministry of Defence, Army Department. Army Personnel Research Establishment Report no. I/66.

Ministry of Agriculture, Fisheries and Food (1970). Manual of Nutrition. London: H. M. Stationery Office. 
Platt, B. S. (1962). Spec. Rep. Ser. med. Res. Coun. no. $3 \circ 2$.

Ruck, N. (1974). Proc. Nutr. Soc. 33, I7A.

Sahashi, Y., Suzuki, T., Higaki, M. \& Asano, T. (1967). F. Vitam. 13, 33.

Swan, C. H. J. \& Cooke, W. T. (197I). Lancet ii, 456.

Tanner, J. M., Whitehouse, R. H. \& Takaishi, M. (1966). Archs Dis. Childh. 41, 454.

Vaishnava, H. P. \& Rizvi, S. N. A. (1967). Br. med. F. i, 112.

Vaishnava, H. P. \& Rizvi, S. N. A. (1971). Lancet ii, 1147.

Vaishnava, H. P. \& Rizvi, S. N. A. (1973). Lancet ii, 621.

Watt, B. K. \& Merrill, A. L. (1963). Composition of Foods; Raw, Processed, Prepared. Washington, DC: US Agricultural Research Service.

Widdowson, E. M. (1947). Spec. Rep. Ser. med. Res. Coun. no. 257. 